\title{
Author Correction: Endogenous Annexin-A1 Regulates Haematopoietic Stem Cell Mobilisation and Inflammatory Response Post Myocardial Infarction in Mice In Vivo
}

\begin{abstract}
Cheng Xue Qin ${ }^{1,2}$, Siobhan B. Finlayson ${ }^{1,3,4}$, Annas Al-Sharea ${ }^{1,4}$, Mitchel Tate ${ }^{1}$, Miles J. De Blasio ${ }^{1,5}$, Minh Deo ${ }^{1}$, Sarah Rosli ${ }^{1,6}$, Darnel Prakoso ${ }^{1,5}$, Colleen J. Thomas ${ }^{3}$, Helen Kiriazis ${ }^{1}$, Eleanor Gould ${ }^{1}$, Yuan H. Yang 6 , Eric F. Morand $\mathbb{1}^{6}$, Mauro Perretti $\mathbb{D}^{8}$, Andrew J. Murphy ${ }^{1,7}$, Xiao-Jun Du ${ }^{1,4}$, Xiao-Ming Gao ${ }^{1}$ \& Rebecca H. Ritchie ${ }^{1,2,4}$
\end{abstract}

Correction to: Scientific Reports https://doi.org/10.1038/s41598-017-16317-1, published online 30 Nobemver 2017

The original version of this Article contained a typographical error in the spelling of the author Annas Al-Sharea, which was incorrectly given as Annas AI-Sharea. This has now been corrected in the PDF and HTML versions of the Article.

(i) Open Access This article is licensed under a Creative Commons Attribution 4.0 International License, which permits use, sharing, adaptation, distribution and reproduction in any medium or format, as long as you give appropriate credit to the original author(s) and the source, provide a link to the Creative Commons license, and indicate if changes were made. The images or other third party material in this article are included in the article's Creative Commons license, unless indicated otherwise in a credit line to the material. If material is not included in the article's Creative Commons license and your intended use is not permitted by statutory regulation or exceeds the permitted use, you will need to obtain permission directly from the copyright holder. To view a copy of this license, visit http://creativecommons.org/licenses/by/4.0/.

(C) The Author(s) 2018

\footnotetext{
${ }^{1}$ Baker Heart \& Diabetes Institute, Melbourne, 3004, Australia. ${ }^{2}$ Dept of Pharmacology and Therapeutics, University of Melbourne, Parkville, 3010, Australia. ${ }^{3}$ Dept of Physiology, Anatomy and Microbiology, La Trobe University, Bundoora, 3086, Australia. ${ }^{4}$ Dept of Medicine, Central Clinical School, Monash University, Melbourne, 3004, Australia. ${ }^{5}$ School of Biosciences, University of Melbourne, Parkville, 3010, Australia. ${ }^{6}$ Centre for Inflammatory Diseases, Monash University, Clayton, 3168, VIC, Australia. ${ }^{7}$ Department of Immunology, Monash University, Melbourne, 3004, VIC, Australia. ${ }^{8}$ William Harvey Research Institute, Barts and The London School of Medicine, Queen Mary University of London, London, United Kingdom. Xiao-Ming Gao and Rebecca H. Ritchie jointly supervised this work. Correspondence and requests for materials should be addressed to C.X.O. (email: chengxuehelena.qin@baker.edu.au) or R.H.R. (email: rebecca.ritchie@baker.edu.au)
} 